\title{
Development Pattern of Rural Tourism based Creative Economy
}

\author{
S. Marhanah, E. Sukriah \\ Department Resort \& Leisure Management, Faculty of Social Science Education \\ Universitas Pendidikan Indonesia \\ srimarhanah@upi.edu
}

\begin{abstract}
The purpose of this research is to identify the potential of tourist attractions that based creative economy, and then to analyze how ready the Cikole Village as a rural tourism based creative economy, and the last to developing the development pattern of rural tourism based creative economy in Cikole Village. The result of this research is about potential which based creative economy on Cikole Village such as: a) Bamboo Crafts; b) Beads Crafts; c) Sisingaan Crafts; and d) An Art Showcase. Talking about the readiness of facilities in Cikole Village as rural tourism based creative economy; the facilities that provided in Cikole Village is all ready to become a rural tourism; likewise, for the materials and the local community is already with the rural tourism activities. The development pattern which could be done to form Cikole Village as a rural tourism based creative economy such as : a) Strengthen the physical form of a village; b) Preparation and provision place to stay (home stay) which of course selected based on characteristic architecture of a village building; c) Provide a workshop and souvenir booth of Cikole Village's crafts; d) Create a map and also an accessibility route in rural tourism activities so tourists can be clear educated when they come and visit to the Cikole Village.
\end{abstract}

Keyword : ruraltourism, creativeeconomy, tourism, cikolevillage

\section{INTRODUCTION}

Indonesia is the largest archipelago in the world which has an area of $5120 \mathrm{~km}$ from west to east and $1750 \mathrm{~km}$ from south to north. Indonesia also has a cultural diversity and amazing tourist destinations. Evidently, Indonesia 's image as a tourism destination in the eyes of the world improved. The World Economic Forum ranks the tourism image of the countries in the world. In 2013 the position of Indonesia increased from rank 74th to become the 70th of 140 countries.

Bandung is one of the major tourist destinations in the province of West Java. Bandung, which are located adjacent to the capital of Indonesia also has so many beautiful panorama and interesting places that becoming a tourist destination. Bandung which is the third largest city in Indonesia after Jakarta and Surabaya, has an interesting tourist rides that well worth to visit from nature tourism, culinary tours, historical tours, and shopping. Bandung popularity has increased since the opening of Cipularang toll, so that access to Bandung become easier. Currently, more than $70 \%$ of locally-generated revenue in Bandung gained from tourism sector. So, no wonder if the Government of Bandung was more aggressively to market its tourist attractions, not only to domestic tourists, but also foreign tourists (http://www.prfmnews.com).

Cikole village is a forest village which located beneath the wildlife sanctuary of Tangkuban Perahu, Lembang District, West Bandung Regency, which has the potential to be developed into a rural tourism. Cikole Village has a potential such as natural attractions, culture, and also potential in creative economy industry. As we can see nowadays most of the community in Cikole Village work as a farmer, stock farmer, and the people who work in creative economy industry. Even from the data which collected from Cikole Village's Goverment Office, about 1100 people work as a merchant in the tourist attraction,which is Tangkuban Perahu.

Based on the formulation of the problem which has been described previously, the purpose of this study was to:1). Identify a potential tourist attraction based creative economy in the Cikole Village; 2). Analyze the readiness of Cikole Village as a rural tourism based creative economy; 3). Developing a pattern of rural tourism based creative economy in Cikole Village.

\section{RURAL TOURISM}

Extensively about the motion of rural tourism which has a broader scope of study, Nuryanti (1993) [1] says that the rural tourism is a form of integration among attractions, accommodation, and support facilities which are presented in the structure of a society that integrates with the procedures and traditions prevailing. In this definition, it is clear that rural tourism emphasizes the tourists to blend with the existing structure of life and explores the local wisdom. That opinion also supported by the Ministry of Tourism that is now becoming the Ministry of Tourism and Creative Economy in a program called Pariwisata Inti Rakyat (PIR). PIR gives the sense that the rural tourism is a rural area that offers the whole atmosphere that reflects both rural authenticity of socioeconomic, socio-cultural, customs, daily life, has the architecture and spatial structure of a typical village, or even unique economic activity and interesting and has the potential to be developed by the various components of tourism. 


\section{TOURIST ATTRACTIONS}

Tourist attraction is anything that has a uniqueness, beauty and value in the form of natural diversity richness, culture and the result of man-made that were targeted or becoming a purpose of tourists visiting. So in some of tourist area, the attractiveness is becoming an important element in the world of tourism. Where some places who has a uniqueness, beauty and cultural diversity is already own a tourist attraction that makes the tourists come to visit. According to Spillane (2002), Tourism attractions are the things that attract the attention of tourists which is owned by a tourist destination. Tourist attraction itself has its own ability to attract tourists to visit. Things that can attract tourists to visit tourist destinations include:

1) Natural Amenities, are objects that are already available and already exist in nature. Example: climate, landforms, landscapes, flora and fauna, and others.

2) Man Made Supply, is the work of man as objects of historic, cultural and religious.

3) Way of Life, is a traditional way of life, habits, customs such as cremation in Bali, sekaten ceremony in Jogjakarta.

4) Culture, is a habit that is owned by people who live in the area attractions.

The criteria of a village to becoming a rural tourism, including:

1) Have the potential and the typical tourist attraction as a tourist destination;

2) Have the support and readiness of the tourism support facilities that associated with rural tourism activities which may include accommodation / lodging, community interaction space with tourists / guests, and other supporting facilities

3) There are support, initiatives, and participation of the local communities for the development of the village itself related to the tourism activities.

\section{Based Creative Economy Tourism}

In the development of the creative economy through tourism sector, a creativity will stimulate tourist destination to create innovative products that will provide an adding value and create higher competitiveness compared to other tourist destinations. From the tourist's side, they will be more interested to visit tourist areas that has a distinctive product to then taking it home as a souvenir. Based on the Department of Commerce, there are 14 sectors that included in the creative economy:
1) Advertising
2) Architecture
3) An Arts Market
4) Crafts
5) Design
6) Fashion
7) Movies, videos, dan photography
8) Interactive games
9) Music
10) An Art Showcase
11) Publishing and Printing
12) Computer service and software
13) Radio and television
14) Research and Development $(R \& D)$

Potential of Tourist Attraction Based Creative Economy in Cikole Village

\section{A. Crafts}

Crafts is one of the most creative industry in Indonesia. This is certainly supported by the abundance of natural resources such as wood, bamboo, or rattan. Indonesian society can freely create handmade products in any form. In the Cikole Village, there are some people who have expertise in handicrafts.

\section{1) Bamboo Crafts}

Most of the people making crafts with bamboo as the base material. The bamboo is processed and formed into various types. Starting from key chains, pens, flute, kitty, animal-shaped wooden carving, bags, and others. Based on the interview between author with Usep, one of the bamboo's craftsmen. He said "bamboo partly derived from Cikole Village, but bamboo in the village is not sufficient, so we took the bamboo from elsewhere, some of them are from Subang".

\section{2) Craft of beads}

The beads are small objects with holes in the middle, whose function is to insert the string or yarn into it which is then assembled according to the desired shape. The function of the bead itself to society is widely used as jewelry.

\section{3) Sisingaan Craft}

In the Cikole village there is also a sisingaan craft. However, this type of craft is not commonly found in the Cikole Village. This sisingaan craft is the home industry that using a simple equipment such as nails, hammers, wood, fabric, chisel, and sewing tools.

\section{B. Arts Performing}

The community in Cikole VIllage are generally Sundanese and most of them are using Sundanese language in their daily life. In one of the Pillars of Citizens (also known as Rukun Warga or RW) in the Cikole village which is Kampung Cibedug RW13, they are still retain their ancestral's values that they teachings beliefs and also they still using a tribal clothing of Sunda region that called as "pangsi" which is often be used during the traditional ceremonies, as well as on the art performing that shown in Kampung Cibedug RW. 13.

Cikole Village's readiness as Rural Tourism Based Creative Economy

Based on observations in the Cikole Village authors would classify a rural tourism readiness in terms of the existing facilities in the Cikole Village; Human Resources (HR) that having competencies in supporting the activities of the rural tourism; and then last in terms of resources or raw materials in the Cikole Village.

Natural Resources and Human Resources (HR) Readiness in the Cikole Village

What is meant by the readiness of resources and human resources in the village Cikole is, the availability of resources or raw materials that used by the artist in making the handicraft. Likewise, with human resources, which namely as the availability and capability of the 
community in making the kinds of handicrafts in the Cikole Village. More detail can be seen in the table. 1

TABLE I. AVAILABILITY OF RAW MATERIALS AND HUMAN RESOURCES IN THE CIKOLE VILLAGE

\begin{tabular}{|l|l|l|l|}
\hline $\begin{array}{l}\text { Kind of } \\
\text { Crafts }\end{array}$ & $\begin{array}{l}\text { Base } \\
\text { Materials }\end{array}$ & $\begin{array}{l}\text { Availability of } \\
\text { The Raw } \\
\text { Materials }\end{array}$ & $\begin{array}{l}\text { Availability of } \\
\text { The Human } \\
\text { Resources }\end{array}$ \\
\hline $\begin{array}{l}\text { Bamboo } \\
\text { Cratfs }\end{array}$ & Bamboo & Available & Available \\
\hline Beads Crafts & Beads & Available & Available \\
\hline $\begin{array}{l}\text { Sisingaan } \\
\text { Craft }\end{array}$ & $\begin{array}{l}\text { Woods and } \\
\text { Wrapping }\end{array}$ & Available & Available \\
\hline
\end{tabular}

According to the table 4.24 , it can be explained that viewing of the types of crafts, the raw materials that used as well as the availability of human handicrafts are able to make the kinds of such handicrafts, and it can be conclude by the authors that the readiness of resources or raw materials and human resources in Cikole village is ready to support and be part of the Rural Tourism. It's just that not all of the raw materials that used there are available at the Cikole Village, some raw materials imported from other places like Majalengka. However, the most important is; based on interviews with the artist in the Cikole Village and interviews with the local figure; they say they are ready and happy if Cikole Village could be change into a rural tourism. Development Patterns of Cikole Village as a Rural Tourism Based Creative Economy

In rural tourism development efforts based creative economy, that viewing from the readiness of the craftsmen and availability of raw materials in the Cikole Village, there are some patterns of development that the authors recommend, among which:

1) Before becoming a rural tourism, one thing that need to be strengthened is the hallmark of a village, either in the form of physical and non-physical. In this study, it should be emphasized that: making an arch which it shape is typical of the Cikole Village, the gate is the entrance to the Cikole Village.

2) Preparation and provision place to stay (home stay) which of course selected based on characteristic architecture of a village building which has a typical of the interior and exterior, so that tourists can feel a different experience when they stay in the village Cikole

3) Provide a workshop and souvenir booth of Cikole Village's crafts so tourists can see and learn directly from the craftsmen how to make any kinds of Cikole's handicraft; making crafts booths which is the center of the types of souvenirs crafts produced by Cikole's villagers.

4) Create a map and also an accessibility route in rural tourism activities so tourists can be clear educated when they come and visit to the Cikole Village. So tourists who come are clear and well known about the schedule of any activities in Cikole Village.

5) Conclusion
6) Based on the results of research conducted on the pattern of rural tourism development based creative economy, it can be concluded as follows:

7) Potential based creative economy in the Cikole Village namely: a) bamboo crafts; where the types of crafts are made from bamboo in the Cikole Village very diverse, such as: pen, keychain holder, various kinds of ornaments from bamboo, wicker, and etc; b) beads crafts ; which type beads-base crafts were also that much, such as key chains, hair tie, and various other accessories; c) sisingaan craft; where that crafts are made with a variety of functions, such as used for toys and also used as sisingaan itself and also can be ride by humans.

8) Cikole Village's readiness as a rural tourism based creative economy seen from three aspects, namely physical aspects encompassing both core facility or tourists activities-supporting facilities, raw materials or human resources aspects who are competent or can be called as craftsmen. Based on observations and interviews with the community and local figure, that the existing facilities in the Cikole Village was ready in case Cikole village someday would change into a rural tourism; as well as the raw materials and craftsmen, they are all ready with the activities of the rural tourism, because of the presence of the rural tourism activities can be certainly develop and improve the welfare of local communities.

9) The pattern of development that can be done to make the Cikole Village as a Rural Tourism based creative economy, including:

a) Strengthening the physical form and nonphysical form of a village

b) Preparation and provision of palce to stay (home stay) home that has certainly been the hallmark of the architecture of a village.

c) Providing workshops and souvenir booths that shows the making of handicrafts Cikole Village

d) Making maps and travel route in the activities of the tourist village, so that tourists can be clear know when they come and visit the Cikole Village

\section{SUGGESTION}

Based on the findings in the field as well as the results of research on develpment pattern of rural tourism in the Cikole Village based creative economy, there are some suggestions or recommendations to several parties, among others:

1) For the Cikole Village community, the magnitude of the potential for rural tourism development based on the creative economy can serve as a foundation to start thinking about a real step in the pattern of rural tourism development based creative economy. Community together with relevant stakeholders can begin to form a container as a manager to immediately implement the research that has been done.

2) For the government of Cikole Village, development pattern of rural tourism based creative economy that sourced from the public must be fully 
supported and given the various facilities within their authority.

3) For other researchers whom interested in other similar reseach, it is recommended that they could examines about the participation of the community and the formation of managers in the development of rural tourism in the Cikole Village based creative economy.

\section{REFERENCES}

[1] Documentation. 2012.Tourism Department of Regency/City In West Java Province

[2] Moleong, Lexy. Metodologi Penelitian Kualitatif. Bandung: PT. Remaja Rosdakarya. 2002.

[3] Nuryanti, Wiendu. Concept, Perspective, and Challenges: Laporan Konferensi Internasional mengenai Pariwisata budaya. Yogyakarta: Gadjah Mada University Press. 1993.

[4] Nuryanti, Wiendu. Perencanaan pembangunan regional dan kawasan untukkepariwisataan alam, makalah disampaikan pada diklat peningkatan mutuprofesionalisme pengelola obyek dan daya tarik pariwisata. 1994.

[5] Spillane, JJ. EkonomiPariwisataSejarahdanProspeknya. Yogyakarta: Kanisius. 2002.

[6] Act No.22 on Regional Goverannce

[7] http://travel.okezone.com/read/2013/12/27/407/918084/2013citra-kepariwisataan-indonesia-semakin-baik-di-mata-dunia (Thursday, 13th of February 2014, 15.30 p.m.)

[8] http://www.prfmnews.com/?cmd=info\&tmplt=2\&vr=2954\&pos=a

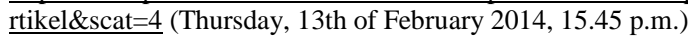

